\title{
Efek Ketebalan Casing dan Ketebalan Media Terhadap Hasil Jamur Merang (Volvariella volvaceae)
}

\author{
The Effect of Casing and Media Thickness to the Crop of \\ Paddy Straw Mushroom (Volvariella volvaceae) \\ Rosnina AG, Elvira Sari Dewi dan Nanda Wahyudi \\ Jurusan Agroteknologi Fakultas Pertanian Universitas Malikussaleh \\ Muara Batu Lhokseumawe
}

\begin{abstract}
Abstrak
Jamur merang dalam bahasa Aceh disebut kulat jumpung/paddy straw mushroom (Volvariella volvaceae) termasuk jamur yang paling dikenal diantara beberapa spesies jamur yang dibudidayakan di Indonesia. Kajian ini bertujuan untuk mengetahui Efek ketebalan casing dan komposisi media terhadap hasil jamur merang (Volvariella volvaceae) dengan menggunakan Rancangan Acak Lengkap (RAL) faktorial dengan tiga ulangan. Faktor pertama yaitu komposisi media dan faktor kedua adalah ketebalan casing. Pengujian data statistik dilakukan dengan menggunakan software SAS V9.12 dan Uji lanjut dengan uji Duncan pada taraf $5 \%$. Percobaan ini menunjukkan terdapat pengaruh nyata pada interaksi antara perlakuan komposisi media dan perlakuan ketebalan casing $\left(\mathrm{K}_{1} \mathrm{C}_{1}\right.$ dan $\left.\mathrm{K}_{0} \mathrm{C}_{1}\right)$ terhadap berat tubuh buah (pin head) per-periode panen, dan tidak terdapat interaksi terhadap peubah lainnya. Sementara komposisi media secara tunggal berpengaruh nyata pada panjang tubuh buah dan jumlah tubuh buah pada perlakuan komposisi media TKKS + kapur + bekatul + tepung jagung $\left(\mathrm{K}_{1}\right)$. Pada peubah lainnya, meski secara statistik belum menunjukkan perbedaan, namun secara rataan terlihat bahwa media TKKS + kapur + bekatul + tepung jagung $\left(\mathrm{K}_{1}\right)$ memiliki frekuensi panen, diameter tubuh buah, panjang dan jumlah tubuh buah serta berat tubuh buah lebih tinggi dibandingkan dengan perlakuan lainnya. Sedangkan rerata munculnya pin head jamur merang nilai tertinggi terdapat pada perlakuan $\left(\mathrm{K}_{0}\right)$. Rata-rata perlakuan tanpa casing $\left(\mathrm{C}_{0}\right)$ selain berpengaruh terhadap panjang tubuh buah (fruting bodi) juga memberi nilai tertinggi pada kemunculan pin head (bakal tubuh buah), frekuensi panen, diameter tubuh. Sementara munculnya pin head, jumlah tubuh buah dan berat tubuh buah jamur merang secara rataan memiliki nilai tertinggi pada perlakuan ketebalan casing $5 \mathrm{~cm}\left(\mathrm{C}_{1}\right)$.
\end{abstract}

Kata Kunci: Jamur merang, komposisi media, ketebalan casing

\begin{abstract}
The mushroom in the Acehnese language is called the bowl/addy straw mushroom (Volvariella volvaceae) including the most well known fungi among several species of mushrooms cultivated in Indonesia. The purpose of this research is to study the effect of the thickness of the casing and the composition of the media on the yield of mushroom (Volvariella volvaceae) using a Factorial Randomized Design with three replications. The first factor is the composition of the media and the second factor is the thickness of the casing. Data analysis was done by using SAS V9.12 software and advanced test with Duncan test at 5\% level. This experiment showed that there is a significant effect on the interaction between the treatment of the media composition and the thickness treatment of the casing ( $\mathrm{K} 1 \mathrm{C} 1$ and $\mathrm{K} 0 \mathrm{C} 1)$ on the head body weight per harvest period, and there is no interaction with other variables. While the composition of the media singularly significant effect on the length of the fruit body and the number of fruit body in the treatment of the composition of oil palm empty bunches + lime + bran + cornflour (K1). In other variables, although statistically not yet showing the difference, but on average it appears that the medium of oil palm empty bunches + lime + bran + cornflour (K1) has the frequency of harvest, fruit body diameter, fruit body length and total body weight and fruit weight is higher than the treatment others. While the average appearance of mushroom pin head of the highest value is in treatment (K0). Average treatment without casing ( $\mathrm{C} 0)$ in addition to affect the body length of the fruit (fruting body) also gives the highest value on the appearance of pin head (going to fruit body), harvest frequency, body diameter. While the appearance of the pin head, the number of fruit body and body weight of mushroom fruit perang has the highest value on the $5 \mathrm{~cm}$ thickness casing treatment $(\mathrm{C} 1)$.
\end{abstract}

Keywords: Mushroom, media composition, casing thickness 


\section{Pendahuluan}

Pertumbuhan dan perkembangan jamur sangat tergantung pada kandungan nutrisi yang tersedia di dalam media yang dapat diserap dan digunakan oleh jamur. Sumiati dan Sopha (2009) menyatakan, pada dasarnya media untuk budidaya jamur harus mengandung karbohidrat sebagai sumber vitamin $\mathrm{C}$ dan protein sebagai sumber $\mathrm{N}$ sehingga diperoleh nilai $\mathrm{C} / \mathrm{N}$ optimal yang dibutuhkan untuk mendukung pertumbuhan dan perkembangan miselium. Winarni dan Rahayu (2002) menambahkan, nutrisi terpenting yang dibutuhkan untuk pertumbuhan miselium dan pembentukan badan buah jamur adalah selulosa, hemiselulosa, lignin dan protein.

Tandan kosong kelapa sawit (TKKS) merupakan bahan organik yang sangat baik digunakan sebagai subtrat pertumbuhan jamur merang. Di dalam TKKS banyak mengandung unsur hara atau unsur organik yang dapat dimanfaatkan sebagai media pertumbuhan jamur merang. Sebelum digunakan TKKS sebagai media pertumbuhan terlebih dahulu dilakukan pengomposan dengan menambahkan unsur hara ke dalam TKKS yaitu kapur dan dedak. Jamur merang merupakan salah satu jamur yang dapat tumbuh pada media limbah organik. Jamur merang termasuk dalam golongan jamur saprofit yaitu jamur yang tumbuh pada substrat organik dari tumbuhan yang sudah mati dan akan mengubah substrat menjadi zat yang mudah diserap (BPTP, 2010).

Tandan kosong kelapa sawit ternyata juga sangat baik dimanfaatkan sebagai media tumbuh bagi jamur merang, dan jamur lain yang memang bisa dikonsumsi. Media TKKS mempunyai unsur hara yang juga dibutuhkan oleh jamur (Arofatullah, 2010). Komponen terbesar dari tandan kosong kelapa sawit (TKKS) adalah selulosa (40-60\%), hemiselulosa (20$30 \%$ ) dan lignin (15-30\%). Oleh karena itu, pemanfaatan TKKS sebagai media tanam bagi jamur sangat baik untuk dikembangkan.

Komposisi media yang tepat untuk menunjang produksi jamur merang berkaitan dengan nutrisi yang dibutuhkan jamur agar tetap berproduksi. Komposisi media tumbuh yang digunakan biasanya terdiri dari jerami atau pemanfaatan limbah pertanian lainnya seperti tandan kosong kelapa sawit sebagai media tumbuh utama, penambahan bekatul, kapur dolomit, dan air secukupnya pada saat pengomposan media tumbuh jamur merang. Namun komposisi yang terkandung belum tentu tercukupi untuk kebutuhan nutrisi jamur merang sehingga memerlukan nutrisi yang relatif mudah diserap media tumbuh yang kaya vitamin, mineral untuk memenuhi aktivitas metabolisme selnya. Suplemennya juga relatif murah dan mudah disediakan sendiri oleh pembudidaya jamur. Oleh karena itu perlu dilakukan uji-coba penambahan beberapa nutrisi alternatif lain seperti penggunaan tepung jagung dan efektif mikroorganisme (EM-4) diharapkan dapat memperbaiki kualitas dan produksi badan buah jamur.

Jamur merang sebagai makhluk hidup juga memerlukan tambahan nutrisi untuk pertumbuhan dan perkembangan. Nutrisi tersebut dapat langsung diperoleh dari media secara langsung dalam bentuk unsur, ion, dan molekul sederhana (Gunawan, 2001). Karbon (C) merupakan unsur dasar pembangunan sel dan sumber energi yang diperlukan oleh sel jamur. Tepung jagung merupakan sumber karbohidrat yang memiliki banyak karbon (C) dan nitrogen yang dapat digunakan sebagai tambahan nutrisi pada media tumbuh jamur merang. Selain itu dalam tepung jagung juga terkandung vitamin B1 (thiamin) dan vitamin B2. Kandungan mikroorganisme di dalam EM-4 dapat meningkatkan nutrisi yang tersedia pada substrat, seperti Lactobacillus sp., Rodhopseudomonas sp., dan Streptomyces sp., berperan dalam fiksasi nitrogen dan juga berperan sebagai pendekomposisi substrat jamur merang dan secara keseluruhan dapat menekan pertumbuhan patogen sehingga aktivitas mikroorganisme tersebut dapat mendukung pertumbuhan jamur merang secara optimal (Adisti, 2007).

Jerami adalah hasil samping usaha pertanian berupa tangkai dan batang tanaman serealia yang telah kering, setelah biji-bijiannya dipisahkan. Bahan ini merupakan limbah organik yang dapat digunakan sebagai bahan media tumbuh jamur merang. Jerami padi mengandung $37,71 \%$ selulosa; $21,99 \%$ hemiselulosa; dan $16,62 \%$ lignin. Kandungan selulosa yang cukup tinggi ini dapat dimanfaatkan dalam berbagai hal antara lain sebagai bahan media tumbuh jamur merang (Pratiwi et al., 2016). Namun, jerami tidak hanya dapat digunakan sebagai media tumbuh jamur merang, tetapi juga dapat digunakan sebagai casing di atas media tumbuh jamur merang. Peletakan casing jerami di atas 
media yang telah dikompos dengan ketebalan tertentu dapat membentuk mikroklimat/kondisi ruangan yang lembab akan dapat merangsang pertumbuhan tubuh buah jamur serta dalam tumpukan jerami pada saat pengomposan terjadi pembebasan unsur hara dari senyawa organik menjadi senyawa anorganik yang tersedia dan tercukupi sebagai nutrisi bagi pertumbuhan jamur merang. Dari latar belakang tersebut maka perlu adanya penelitian tentang "Pengaruh Komposisi Media dan Ketebalan Casing Terhadap Pertumbuhan dan Hasil Jamur Merang (Volvariella volvaceae)".

Penenelitian ini bertujuan untuk mengetahui pengaruh komposisi media dan ketebalan casing yang berbeda terhadap pertumbuhan dan hasil jamur merang serta mengetahui interaksi antara komposisi media dan ketebalan casing terhadap pertumbuhan dan hasil jamur merang.

\section{Bahan dan Metode}

Penelitian ini dilaksanakan pada kumbung (rumah jamur) di Gang Pemda Desa Hagu Teungoh, Kecamatan Banda Sakti, Kota Lhokseumawe. Penelitian dilaksanakan mulai dari bulan Juni sampai Juli 2017. Bahan yang digunakan adalah benih jamur merang F3, tandan kosong kelapa sawit (TKKS), jerami, bekatul, kapur dolomit $\left(\mathrm{CaMg}\left(\mathrm{CO}_{3}\right)_{2}\right)$, tepung jagung, efektif mikroorganisme (EM-4), alkohol $70 \%$, dan air. Sedangkan Alat yang digunakan diantaranya adalah termometer, $\mathrm{pH}$ meter, higrometer, alat ukur (penggaris), jangka sorong, steamer, handsprayer, masker, sarung tangan, keranjang, kereta sorong (troli), selang air, terpal plastik, tali rafia, timbangan, kertas label, alat tulis, dan alat dokumentasi.

Penelitian dilakukan didalam kumbung menggunakan Rancangan Acak Lengkap (RAL) faktorial yang terdiri dari dua faktor. Faktor pertama yaitu: Komposisi Media (K) yang terdiri: $\mathrm{K} 0=$ TKKS + kapur + bekatul (kontrol), $\mathrm{K} 1$ = TKKS + kapur + bekatul + tepung jagung, $\mathrm{K} 2=\mathrm{TKKS}+$ kapur + bekatul + EM-4. Faktor kedua yaitu: Ketebalan Casing (C) yang terdiri $\mathrm{C} 0=$ Tanpa casing (kontrol), $\mathrm{C} 1=5 \mathrm{~cm}, \mathrm{C} 2=7$ $\mathrm{cm}$.

Perlakuan komposisi media dilakukan pada saat pengomposan media TKKS sebelum dimasukkan ke dalam kumbung. Sedangkan ketebalan casing dilakukan sesudah pengomposan dan pada saat media diletakkan pada petak percobaan. Setiap perlakuan terdapat 9 kombinasi perlakuan dan diulang 3 kali sehingga terdapat 27 petak percobaan. Setiap masing-masing petak percobaan berukuran 8300 $\mathrm{cm}^{2}$ luas media tumbuh jamur merang yang diletakkan dalam petak percobaan, dan setiap petak percobaan diambil $10 \%$ dari jumlah jamur merang untuk masing-masing sampel pengamatan. Data hasil pengamatan dianalisis dengan ANOVA dan bila terdapat perbedaan nyata dilanjutkan dengan uji Duncan pada taraf 5 $\%$ untuk membandingkan rata-rata antar perlakuan. Model matematika yang digunakan untuk Rancangan Acak Lengkap (RAL) pola faktorial adalah:

\section{Keterangan :}

$$
Y i j k=\mu+\mathrm{Ki}+\mathrm{Cj}+(\mathrm{KC}) \mathrm{ij}+\varepsilon \mathrm{ijk}
$$

Yijk = Nilai pengamatan untuk faktor komposisi media (K) pada taraf ke-i dan faktor ketebalan casing (C) pada taraf ke-j dan ulangan ke-k

$\mu \quad=\quad$ Rata-rata (nilai tengah)

$\mathrm{Ki} \quad=$ Pengaruh faktor komposisi media (K) ke-i.

$\mathrm{Cj}=$ Pengaruh faktor ketebalan casing $(\mathrm{C}) \mathrm{ke}-\mathrm{i}$

$(\mathrm{KC}) \mathrm{ij}=$ Pengaruh interaksi pada faktor komposisi media $(\mathrm{K})$ taraf ke-i dan faktor ketebalan casing (C) pada taraf ke-j

$\varepsilon$ ijk $=$ Galat percobaan

\section{Pelaksanaan Penelitian \\ Pembuatan Kumbung}

Kumbung yang digunakan terbuat dari rangka bambu. Ukuran kumbung yaitu lebar 2,5 $\mathrm{m}$, panjang $3,5 \mathrm{~m}$, dan tinggi $4 \mathrm{~m}$. Bagian atas dinding kumbung perlu dibuatkan ventilasi berupa jendela dengan ukuran $60 \times 40 \mathrm{~cm}$ yang digunakan sebagai tempat keluar masuk udara (aerasi). Sementara itu, pada lapisan dinding bagian bawah perlu dibuatkan pintu sebagai tempat keluar masuk ke dalam kumbung yang dapat dibuka dan ditutup kembali. Dinding kumbung terbuat dari terpal plastik agar biayanya semakin murah, sementara untuk bagian atap digunakan daun rumbia. Rak kumbung dibuat dengan rangka bambu sebanyak 8 rak tumbuh dengan ukuran panjang 3,5 $\mathrm{m}$ dan lebar $0,80 \mathrm{~m}$ terdiri dari 4 tingkat sebelah kiri dan sebelah kanan dan setiap tingkatan memiliki jarak masing-masing $60 \mathrm{~cm}$. Temperatur dalam ruangan kumbung diusahakan agar selalu terjaga, yaitu berkisar antara $29-38{ }^{\circ} \mathrm{C}$. Untuk menjaga agar suhu di dalam kumbung tetap stabil dengan 
membuka ventilasi berupa jendela jika suhunya tinggi melebihi $38^{\circ} \mathrm{C}$ dan dilakukan penyiraman pada lantai dasar kumbung apabila suhunya rendah kurang dari $29^{\circ} \mathrm{C}$.

\section{Pengomposan Media Tumbuh dan Media Casing Jerami}

Bahan baku utama tandan kosong kelapa sawit (TKKS) sebanyak 18 unit kereta sorong (troli) atau dengan berat TKKS $540 \mathrm{~kg}$, kemudian direndam dengan air dalam bak ukuran 3 x 1,5 meter dan ditambahkan atau ditaburkan kapur dolomit sebanyak $6 \mathrm{~kg}$ sampai merata kemudian dibiarkan selama 48 jam agar bisa digunakan untuk pengomposan media tumbuh TKKS. Adapun pengunaan komposisi media TKKS yaitu bekatul sebanyak $18 \mathrm{~kg}$, kapur dolomit $12 \mathrm{~kg}$, tepung jagung $1 \mathrm{~kg}$, dan EM-4 dengan konsentrasi $10 \mathrm{ml} / \mathrm{liter}$ air. Namun penggunaan komposisi media tersebut sesuai dengan perlakuan masing-masing komposisi media tumbuh. Pada perlakuan kontrol, pengomposan media TKKS sebanyak 6 troli dicampurkan dengan bekatul sebanyak $6 \mathrm{~kg}$, kapur dolomit sebanyak $4 \mathrm{~kg}$ dan disiram dengan air secukupnya sampai merata. Pada perlakuan komposisi tepung jagung, pengomposan media TKKS sebanyak 6 troli dicampurkan dengan bekatul sebanyak $6 \mathrm{~kg}$, kapur dolomit sebanyak 4 $\mathrm{kg}$ dan penambahan tepung jagung $1 \mathrm{~kg}$ lalu disiram dengan air secukupnya sampai merata. Pada perlakuan komposisi EM-4, pengomposan media TKKS sebanyak 6 troli dicampurkan dengan bekatul sebanyak $6 \mathrm{~kg}$, kapur dolomit sebanyak $4 \mathrm{~kg}$, lalu disiram dengan air secukupnya, dan penambahan EM-4 sebanyak 10 $\mathrm{ml} /$ liter air dan disemprot secara merata pada media TKKS. Setiap perlakuan komposisi media diberi pembatas berupa plastik yang terdiri dari 3 perlakuan yang di tumpuk dalam satu tumpukan yang ditutup rapat dengan terpal plastik. Proses pengomposan media TKKS dilakukan selama 10 hari, dan dilakukan pembalikan dalam 5 hari sekali. Untuk pengomposan casing, media yang digunakan yaitu jerami sebanyak $35 \mathrm{~kg}$ yang terlebih dahulu direndam dalam air selama 2 jam supaya bebas dari residu pada jerami dan agar rata terkena air pada saat dilakukan pengomposan. Setelah dilakukan perendaman, media casing jerami dikompos dengan penambahan bekatul sebanyak $4 \mathrm{~kg}$ dan kapur dolomit sebanyak $2 \mathrm{~kg}$ lalu disiram dengan air secara merata. Pengomposan media casing jerami dilakukan selama 10 hari dan dilakukan pembalikan 5 hari sekali. Kemudian pengomposan media casing jerami ditutup rapat dengan menggunakan terpal plastik.

\section{Pengisian Media Tumbuh dan Peletakan Casing Jerami}

Media tumbuh TKKS dan media casing jerami yang telah dikompos dimasukkan ke dalam kumbung dan diletakkan di atas rak sesuai perlakuan masing-masing. Setiap tingkatan rak diletakkan media sesuai dengan bagan penelitian pada lampiran 1. Ketebalan media tumbuh TKKS yang digunakan yaitu $15-20 \mathrm{~cm}$. Sedangkan untuk media casing jerami diletakkan di atas media dasar (TKKS) sebelum dilakukan pasteurisasi dengan ketebalan casing jerami sesuai dengan perlakuan masing-masing setiap petak percobaan yaitu tanpa casing (kontrol), 5 $\mathrm{cm}$, dan $7 \mathrm{~cm}$.

\section{Pasteurisasi}

Pasteurisasi merupakan usaha yang dilakukan untuk mensterilkan media dan ruangan dalam kumbung. Pasteurisasi dilakukan dengan cara mengalirkan uap panas sampai dengan temperatur tertentu dengan maksud menghilangkan kadar amoniak $\left(\mathrm{NH}_{3}\right)$, menghilangkan mikroba yang merugikan pertumbuhan jamur terutama yang mengakibatkan penyakit, dan mengaktifkan mikroba yang dikehendaki bermanfaat sehingga terbentuk zat-zat yang lebih sederhana dan siap digunakan pertumbuhan jamur merang (Suhardiman, 2006).

Pasteurisasi dilakukan dengan mengaliri uap panas ke dalam kumbung yang telah ditutup rapat dengan suhu $70{ }^{\circ} \mathrm{C}$ dipertahankan selama 4-5 jam dengan menggunakan steamer berupa drum yang diisi air sekitar 180 liter dengan menggunakan tungku di bawahnya dibakar dengan menggunakan kayu bakar. Setelah mengalirkan uap panas ke dalam kumbung dan dibiarkan selama 24 jam untuk menurunkan suhu (cooling down) hingga $32-35{ }^{\circ} \mathrm{C}$ supaya bisa dilakukan penebaran benih jamur merang.

\section{Penebaran Benih}

Penebaran Benih (spawning) jamur merang dilakukan ketika suhu media yang di pasteurisasi sudah turun mencapai $32-35{ }^{\circ} \mathrm{C}$. Proses inokulasi dilakukan dengan cara penebaran benih secara merata di atas permukaan media yang telah dipasteurisasi dengan suhu $70{ }^{\circ} \mathrm{C}$ dipertahankan selama 4-5 jam. Tiap petak perlakuan dengan luas media 
$8300 \mathrm{~cm}^{2}$ membutuhkan 150 gram benih jamur merang. Setelah dilakukan penebaran benih jamur, kumbung ditutup rapat kembali agar suhu ruang dalam kumbung dipertahankan.

\section{Pemeliharaan}

\section{Pengaturan Suhu dan Kelembaban}

Suhu ruang diusahakan mencapai 29-38 ${ }^{\circ} \mathrm{C}$, sedangkan kelembaban udara 70-80\%. Suhu ruangan dan kelembaban apabila tidak sesuai maka perlu dilakukan penyiraman dan diberi udara dengan cara membuka ventilasi sesuai dengan kebutuhan. Lantai dan dinding dijaga tetap basah, kelembaban tetap tinggi berkisar anatara $80-90 \%$. Tujuannya adalah untuk merangsang pertumbuhan miselium menjadi badan buah jamur yang merata dan bersamaan.

\section{Pengabutan}

Pengabutan dilakukan pada hari keempat setelah benih ditebarkan pada media (spawning). Cara pengabutan adalah dengan menggunakan handsprayer yang diisi dengan air kemudian disemprotkan ke seluruh ruangan dan media tumbuh yang kering.

\section{Penyiraman}

Penyiraman juga dilakukan pada lantai dasar kumbung tanah. Penyiraman dan pengabutan bertujuan untuk mendorong pertumbuhan miselium merata di permukaan dan dalam media tumbuh.

\section{Pencegahan Hama dan Penyakit}

Pencegahan penyakit dan tumbuhnya jamur lain (Coprinus sp) dilakukan dengan pasteurisasi. Pencegahan adanya gangguan dari semut dapat dilakukan secara organik dengan cara menyebar kapur pada lantai dasar kumbung. Panen

Pemanenan dilakukan sebelum badan jamur merang mekar tetapi sudah dalam bentuk besar yang maksimal pada stadia kancing atau telur. Pada hari ke 10-12 HSI, jamur merang sudah siap dipanen. Jamur merang biasanya dipanen saat kuncupnya belum mekar, masih berbentuk bulat dengan warna putih kecoklatan. Pemanenan dilakukan menggunakan tangan dengan cara memutar dan mematahkan tubuh buah sampai pangkalnya. Masa panen jamur merang bisa berlangsung sekitar 1 bulan dengan interval satu hari sekali atau dua kali.

\section{Munculnya Stadia Jarum Pentul (Pin head)}

Pengamatan terhadap pertumbuhan jamur merang dilihat pada saat hari pertama awal munculnya pin head setelah diinokulasi. Pengamatan munculnya pin head diamati satu hari sekali secara visual dengan menggunakan panca indera penglihatan. Pengamatan munculnya stadia jarum pentul (pin head) dihentikan apabila miseliumnya sudah membentuk stadia kancing (button).

\section{Frekuensi Panen}

Frekuensi panen, yaitu menghitung lamanya waktu yang diperlukan untuk memanen semua tubuh buah jamur merang yang sudah mencapai stadia kancing atau telur.

\section{Diameter Tubuh Buah}

Diameter tubuh buah $(\mathrm{cm})$, yaitu ratarata diameter dari seluruh tubuh buah jamur yang dipanen dalam setiap kombinasi perlakuan. Diameter tubuh buah diukur dengan menggukan jangka sorong. Contoh sampel yang diambil yaitu sebanyak $10 \%$ dari jumlah tubuh buah jamur pada setiap petak atau ulangan.

\section{Panjang Tubuh Buah}

Panjang tubuh buah $(\mathrm{cm})$ jamur merang pada tiap perlakuan, diukur dari pangkal batang sampai ujung tudung. Panjang tubuh buah diukur dengan menggunakan penggaris. Contoh sampel yang diambil yaitu sebanyak $10 \%$ dari jumlah tubuh buah jamur pada setiap petak atau ulangan.

\section{Jumlah Tubuh Buah}

Jumlah seluruh tubuh buah jamur merang pada tiap perlakuan (buah), diamati dengan cara menghitung banyaknya jumlah tubuh buah jamur merang yang telah dipanen. Tubuh buah jamur ng telah dipanen tersebut dihitung secara manual pada setiap perlakuan. Hal ini dilakukan pada saat jamur memasuki stadia telur (egg) dengan pengambilan data dilakukan setiap hari.

\section{Berat Tubuh Buah Tiap Panen}

Berat tubuh buah tiap panen (g), merupakan hasil bagi berat total tubuh buah dengan frekuensi panen tubuh buah.

\section{Pengamatan}




\section{Berat Total Tubuh Buah}

Berat total tubuh buah jamur merang (g), yaitu jumlah keseluruhan berat tubuh buah selama panen.

\section{Hasil dan Pembahasan}

Rekapitulasi parameter pengamatan (Tabel 3) menunjukkan bahwa perlakuan faktor tunggal untuk komposisi media tidak berpengaruh nyata terhadap munculnya pin head, frekuensi panen, diameter tubuh buah, berat tubuh buah tiap panen, dan berat total tubuh buah. Tetapi berpengaruh nyata terhadap panjang tubuh buah dan jumlah tubuh buah.
Perlakuan faktor tunggal untuk ketebalan casing tidak berpengaruh nyata terhadap munculnya pin head, frekuensi panen, diameter tubuh buah, jumlah tubuh buah, berat tubuh buah tiap panen, dan berat total tubuh buah. Tetapi berpengaruh nyata terhadap panjang tubuh buah. Terdapat interaksi antara perlakuan komposisi media dan ketebalan casing terhadap berat tubuh buah tiap panen. Rekapitulasi hasil sidik ragam pada peubah yang diamati dapat dilihat pada Tabel 1.

Tabel 1. Tinggi Tanaman Kedel Rekapitulasi Hasil Sidik Ragam Penelitian Pengaruh Komposisi Media dan Ketebalan Casing Terhadap Pertumbuhan dan Hasil Jamur Merang

\begin{tabular}{|c|c|c|c|c|}
\hline \multirow{2}{*}{ Peubah } & \multicolumn{3}{|c|}{ Faktor } & \multirow{2}{*}{ KK } \\
\hline & $\mathbf{K}$ & $\mathbf{C}$ & $\mathbf{K} \times \mathbf{C}$ & \\
\hline Munculnya Pin Head & $2.71^{\mathrm{tn}}$ & $0.57^{\mathrm{tn}}$ & $0.14^{\mathrm{tn}}$ & 28.40 \\
\hline Frekuensi Panen & $1.69^{\operatorname{tn}}$ & $2.22^{\mathrm{tn}}$ & $0.75^{\text {tn }}$ & 8.25 \\
\hline Diameter Tubuh Buah & $1.99^{\operatorname{tn}}$ & $2.61^{\text {tn }}$ & $0.47^{\mathrm{tn}}$ & 8.68 \\
\hline Panjang Tubuh Buah & $3.60^{*}$ & $5.91 *$ & $1.29^{\operatorname{tn}}$ & 10.38 \\
\hline $\begin{array}{l}\text { Jumlah Tubuh Buah } \\
\text { Berat Tubuh Buah Tiap Panen } \\
\text { Berat Total Tubuh Buah }\end{array}$ & $\begin{array}{l}4.89^{*} \\
1.59^{\text {tn }} \\
1.71^{\text {tn }}\end{array}$ & $\begin{array}{l}1.14^{\text {tn }} \\
2.93^{\text {tn }} \\
2.30^{\text {tn }}\end{array}$ & $\begin{array}{l}0.52^{\text {tn }} \\
3.13^{*} \\
2.67^{\text {tn }}\end{array}$ & $\begin{array}{l}20.03 \\
17.18 \\
18.14\end{array}$ \\
\hline \multicolumn{5}{|c|}{$\begin{array}{l}\text { Keterangan : } \mathrm{K}=\text { Komposisi media; } \mathrm{C}=\text { Ketebalan kasing; } \mathrm{HSI}=\text { hari setelah inokulasi; } \mathrm{tn}=\text { tidak nyata; } * * \\
\text { berpengaruh sangat nyata; } *=\text { berpengaruh nyata }\end{array}$} \\
\hline \multicolumn{2}{|c|}{$\begin{array}{l}\text { Munculnya Pin Head } \\
\text { Hasil analisis ragam menunjukkan } \\
\text { bahwa perlakuan kombinasi media tumbuh, } \\
\text { ketebalan casing dan interaksi antara } \\
\text { kombinasi media tumbuh dan ketebalan }\end{array}$} & \multicolumn{3}{|c|}{$\begin{array}{l}\text { casing tidak berpengaruh nyata terhadap } \\
\text { munculnya pin head. Rata-rata munculnya } \\
\text { pin head jamur merang disajikan pada Tabel } \\
2 .\end{array}$} \\
\hline \multicolumn{5}{|c|}{$\begin{array}{l}\text { Tabel 2. Rata-rata Munculnya Pin head Akiba } \\
\text { Ketebalan Casing }\end{array}$} \\
\hline \multicolumn{2}{|l|}{ Perlakuan } & \multicolumn{3}{|c|}{........................ hari .................... } \\
\hline \multicolumn{5}{|l|}{ Perlakuan Komposisi Media } \\
\hline \multicolumn{2}{|l|}{ Kontrol } & \multicolumn{3}{|c|}{$5.22 \mathrm{a}$} \\
\hline \multicolumn{2}{|c|}{ TKKS + kapur + bekatul + tepung jagung } & \multicolumn{3}{|c|}{$4.39 \mathrm{a}$} \\
\hline \multicolumn{2}{|l|}{ TKKS + kapur + bekatul + EM-4 } & \multicolumn{3}{|c|}{$3.83 \mathrm{a}$} \\
\hline \multicolumn{5}{|l|}{ Ketebalan Casing } \\
\hline \multicolumn{2}{|l|}{ Kontrol } & \multicolumn{3}{|c|}{$4.67 \mathrm{a}$} \\
\hline \multicolumn{2}{|l|}{ Casing $5 \mathrm{~cm}$} & \multicolumn{3}{|c|}{$4.67 \mathrm{a}$} \\
\hline \multicolumn{2}{|l|}{ Casing $7 \mathrm{~cm}$} & \multicolumn{3}{|c|}{$4.11 \mathrm{a}$} \\
\hline
\end{tabular}

Keterangan : Angka yang diikuti oleh huruf yang sama pada perlakuan dan peubah yang sama tidak berbeda nyata pada uji DMRT taraf 5\% 
Tabel 2 menunjukkan bahwa munculnya pin head tertinggi pada perlakuan komposisi media TKKS + kapur + bekatul (kontrol). Sedangkan pada perlakuan faktor tunggal ketebalan casing nilai tertinggi terdapat pada dua perlakuan yaitu tanpa casing dan ketebalan casing $5 \mathrm{~cm}$.

\section{Frekuensi Panen}

Frekuensi panen jamur merang dilakukan dengan cara menghitung lamanya waktu yang diperlukan untuk memanen semua tubuh buah jamur merang yang sudah mencapai stadia kancing. Hasil analisis ragam menunjukkan bahwa perlakuan kombinasi media tumbuh, ketebalan casing dan interaksi antara kombinasi media tumbuh dan ketebalan casing tidak berpengaruh nyata terhadap frekuensi panen. Rata-rata frekuensi panen jamur merang disajikan pada Tabel 3.

Tabel 3. Rata-rata Frekuensi Panen Jamur Merang Akibat Perlakuan Komposisi Media Tumbuh dan Ketebalan Casing

\begin{tabular}{lc}
\hline \multicolumn{1}{c}{ Perlakuan } & Frekuensi Panen \\
\cline { 2 - 2 } & $\ldots . . . . . . . . . . . . . . .6$ buah .................. \\
\hline Perlakuan Komposisi Media & $9.00 \mathrm{a}$ \\
Kontrol & $9.66 \mathrm{a}$ \\
TKKS + kapur + bekatul + tepung jagung & $9.33 \mathrm{a}$ \\
TKKS + kapur + bekatul + EM-4 & \\
\hline Ketebalan Casing & $9.66 \mathrm{a}$ \\
Kontrol & $9.11 \mathrm{a}$ \\
Casing 5 cm & $9.22 \mathrm{a}$ \\
Casing 7 cm & \\
\hline
\end{tabular}

Keterangan : Angka yang diikuti oleh huruf yang sama pada perlakuan dan peubah yang sama tidak berbeda nyata pada uji DMRT taraf 5\%

Tabel 3 menunjukkan bahwa nilai tertinggi frekuensi panen terdapat pada perlakuan komposisi media TKKS + kapur + bekatul + tepung jagung. Sedangkan pada perlakuan faktor tunggal ketebalan casing nilai tertinggi terdapat pada perlakuan yaitu tanpa casing.

\section{Diameter Tubuh Buah}

Hasil analisis ragam menunjukkan bahwa perlakuan kombinasi media tumbuh, ketebalan casing dan interaksi antara kombinasi media tumbuh dan ketebalan casing tidak berpengaruh nyata terhadap diameter tubuh buah. Rata-rata diameter tubuh buah jamur merang disajikan pada Tabel 4.

Tabel 4. Rata-rata Diameter Tubuh Buah Akibat Perlakuan Komposisi Media Tumbuh dan Ketebalan Casing

\begin{tabular}{|c|c|}
\hline \multirow{2}{*}{ Perlakuan } & Diamaeter Tubuh Buah \\
\hline & ...................................... \\
\hline Perlakuan Komposisi Media & \\
\hline Kontrol & $1.77 \mathrm{a}$ \\
\hline TKKS + kapur + bekatul + tepung jagung & $1.92 \mathrm{a}$ \\
\hline TKKS + kapur + bekatul + EM-4 & $1.80 \mathrm{a}$ \\
\hline Ketebalan Casing & \\
\hline Kontrol & $1.93 \mathrm{a}$ \\
\hline Casing $5 \mathrm{~cm}$ & $1.79 \mathrm{a}$ \\
\hline Casing $7 \mathrm{~cm}$ & $1.77 \mathrm{a}$ \\
\hline
\end{tabular}


Keterangan: Angka-angka yang diikuti oleh huruf kecil yang sama pada kolom yang sama dan huruf besar yang sama pada baris yang sama berbeda tidak nyata menurut uji Duncan $\alpha=5 \%$.

Tabel 4 menunjukkan bahwa nilai tertinggi diameter tubuh buah terdapat pada perlakuan komposisi media TKKS + kapur + bekatul + tepung jagung. Sedangkan pada perlakuan faktor tunggal ketebalan casing nilai tertinggi terdapat pada perlakuan yaitu tanpa casing.

\section{Panjang Tubuh Buah}

Hasil analisis ragam menunjukkan bahwa perlakuan kombinasi media tumbuh dan ketebalan casing berpengaruh nyata terhadap panjang tubuh buah. Sedangkan interaksi antara kombinasi media tumbuh dan ketebalan casing tidak berpengaruh nyata terhadap panjang tubuh buah. Rata-rata panjang tubuh buah jamur merang disajikan pada Tabel 5.

Tabel 5. Rata-rata Panjang Tubuh Buah Akibat Perlakuan Komposisi Media Tumbuh dan Ketebalan Casing

\begin{tabular}{|c|c|}
\hline \multirow{2}{*}{ Perlakuan } & Panjang Tubuh Buah \\
\hline & 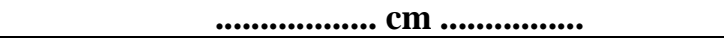 \\
\hline \multicolumn{2}{|l|}{ Perlakuan Komposisi Media } \\
\hline Kontrol & $2.10 \mathrm{~b}$ \\
\hline TKKS + kapur + bekatul + tepung jagung & $2.40 \mathrm{a}$ \\
\hline TKKS + kapur + bekatul + EM-4 & $2.28 \mathrm{ab}$ \\
\hline \multicolumn{2}{|l|}{ Ketebalan Casing } \\
\hline Kontrol & $2.43 \mathrm{a}$ \\
\hline Casing $5 \mathrm{~cm}$ & $2.30 \mathrm{a}$ \\
\hline Casing $7 \mathrm{~cm}$ & $2.05 \mathrm{~b}$ \\
\hline \multicolumn{2}{|c|}{$\begin{array}{l}\text { Keterangan: Angka-angka yang diikuti oleh huruf kecil yang sama pada kolom yang sama dan huruf besar yang } \\
\text { sama pada baris yang sama berbeda tidak nyata menurut uji Duncan } \alpha=5 \% \text {. }\end{array}$} \\
\hline \multirow{2}{*}{\multicolumn{2}{|c|}{\begin{tabular}{ll} 
Tabel 5 menunjukkan bahwa nilai tertinggi & \multicolumn{1}{c}{ Hasil analisis ragam menunjukkan } \\
panjang tubuh buah terdapat pada komposisi & bahwa perlakuan kombinasi media tumbuh dan \\
media TKKS + kapur + bekatul + tepung jagung. & ketebalan casing berpengaruh nyata terhadap \\
Sedangkan pengaruh nyata secara faktor tunggal & jumlah tubuh buah. Sedangkan interaksi antara \\
ketebalan casing terlihat pada panjang tubuh & kombinasi media tumbuh dan ketebalan casing \\
buah jamur merang tanpa casing & tidak berpengaruh nyata terhadap jumlah tubuh \\
Jumlah Tubuh Buah & buah. Rata-rata jumlah tubuh buah jamur \\
& merang disajikan pada Tabel 6.
\end{tabular}}} \\
\hline & \\
\hline \multicolumn{2}{|c|}{$\begin{array}{l}\text { Tabel 6. Rata-rata Jumlah Tubuh Buah Akibat Perlakuan Komposisi Media Tumbuh dan Ketebalan } \\
\text { Casing }\end{array}$} \\
\hline \multirow{2}{*}{ Perlakuan } & Jumlah Tubuh Buah \\
\hline & ....................buah.................. \\
\hline \multicolumn{2}{|l|}{ Perlakuan Komposisi Media } \\
\hline Kontrol & $4.46 \mathrm{~b}$ \\
\hline TKKS + kapur + bekatul + tepung jagung & $5.83 \mathrm{a}$ \\
\hline TKKS + kapur + bekatul + EM-4 & $4.67 \mathrm{~b}$ \\
\hline \multicolumn{2}{|l|}{ Ketebalan Casing } \\
\hline Kontrol & $5.12 \mathrm{a}$ \\
\hline Casing $5 \mathrm{~cm}$ & $5.26 \mathrm{a}$ \\
\hline Casing $7 \mathrm{~cm}$ & $4.58 \mathrm{a}$ \\
\hline
\end{tabular}

Keterangan : Angka yang diikuti oleh huruf yang sama pada perlakuan dan peubah yang sama tidak berbeda nyata pada uji DMRT taraf $5 \%$ 
Berdasarkan Tabel 6 menunjukkan bahwa nilai tertinggi jumlah tubuh buah terdapat pada komposisi media TKKS + kapur + bekatul + tepung jagung. Sedangkan pengaruh nyata secara faktor tunggal ketebalan casing terlihat pada jumlah tubuh buah jamur merang dengan ketebalan casing $5 \mathrm{~cm}$.

\section{Berat Tubuh Buah Tiap Panen}

Berdasarkan hasil analisis ragam menunjukkan bahwa terdapat interaksi antara perlakuan kombinasi media tumbuh dan ketebalan casing terhadap berat tubuh buah tiap panen. Secara tunggal tidak menunjukkan pengaruh nyata terhadap berat tubuh buah tiap panen. Hasil uji lanjut pengaruh perlakuan kombinasi media tumbuh dan ketebalan casing untuk berat tubuh buah tiap panen dengan menggunakan uji DMRT disajikan pada Tabel 7.

Tabel 7. Tabel Interaksi Antara Perlakuan Komposisi Media Tumbuh dan Ketebalan Casing Terhadap Berat Tubuh Buah Tiap Panen

\begin{tabular}{ccccc}
\hline \multirow{2}{*}{ Komposisi Media } & \multicolumn{3}{c}{ Ketebalan Casing } & \multirow{2}{*}{ Total } \\
\cline { 2 - 4 } & $\mathrm{C} 0$ & $\mathrm{C} 1$ & $\mathrm{C} 2$ & \multirow{2}{*}{351,25} \\
K0 & $96.62 \mathrm{bc}$ & $132.41 \mathrm{ab}$ & $122.22 \mathrm{abc}$ & \\
& $(\mathrm{B})$ & $(\mathrm{AB})$ & $(\mathrm{AB})$ & \multirow{2}{*}{ K } \\
K1 & $115.68 \mathrm{abc}$ & $139.94 \mathrm{a}$ & $90.21 \mathrm{c}$ & \\
& $(\mathrm{AB})$ & $(\mathrm{A})$ & $(\mathrm{B})$ & 306,98 \\
K2 & $116.98 \mathrm{abc}$ & $97.52 \mathrm{bc}$ & $92.48 \mathrm{c}$ & \\
& $(\mathrm{AB})$ & $(\mathrm{B})$ & $(\mathrm{B})$ & 1004,06 \\
\hline
\end{tabular}

Keterangan : Angka yang diikuti oleh huruf yang sama pada perlakuan dan peubah yang sama tidak berbeda nyata pada uji DMRT taraf 5\%.

Berdasarkan Tabel 7 menunjukkan interaksi antara perlakuan kombinasi media tumbuh dan ketebalan casing berpengaruh nyata terhadap berat tubuh buah tiap panen jamur merang. Nilai tertinggi terdapat pada perlakuan komposisi media TKKS + kapur + bekatul + tepung jagung dan ketebalan casing $5 \mathrm{~cm}$.

\section{Berat Total Tubuh Buah}

Hasil analisis ragam menunjukkan bahwa tidak ada interaksi antara perlakuan kombinasi media tumbuh dan ketebalan casing terhadap berat total tubuh buah. Hasil uji lanjut pengaruh perlakuan kombinasi media tumbuh dan ketebalan casing secara tunggal untuk berat total tubuh buah dengan menggunakan uji DMRT disajikan pada Tabel 8.

Tabel 8. Rata-rata Berat Total Tubuh Buah Akibat Perlakuan Komposisi Media Tumbuh dan Ketebalan Casing

\begin{tabular}{lc}
\hline \multicolumn{1}{c}{ Perlakuan } & Berat Total Tubuh Buah \\
\cline { 2 - 2 } & ...................gram................. \\
\hline Perlakuan Komposisi Media & $1050.44 \mathrm{a}$ \\
Kontrol & $1115.78 \mathrm{a}$ \\
TKKS + kapur + bekatul + tepung jagung & $952.33 \mathrm{a}$ \\
TKKS + kapur + bekatul + EM-4 & \\
\hline Ketebalan Casing & $1056.56 \mathrm{a}$ \\
Kontrol & $1125.22 \mathrm{a}$ \\
Casing 5 cm & $936.78 \mathrm{a}$ \\
Casing 7 cm & \\
\hline
\end{tabular}

Keterangan: Angka yang diikuti oleh huruf yang sama pada perlakuan dan peubah yang sama tidak berbeda nyata pada uji DMRT taraf 5\% 
Berdasarkan Tabel 10 menunjukkan bahwa faktor perlakuan komposisi media secara tunggal tidak berpengaruh nyata terhadap berat total tubuh buah jamur merang. Akan tetapi secara rataan, berat total tubuh buah jamur merang tertinggi terdapat komposisi media TKKS + kapur + bekatul + tepung jagung dibandingkan dengan perlakuan lainnya. Sedangkan, faktor ketebalan casing secara tunggal juga tidak memberikan pengaruh yang nyata pada peubah berat tubuh buah jamur merang. Akan tetapi nilai rata-rata berat tubuh buah jamur merang tertinggi terdapat pada jamur merang dengan ketebalan casing $5 \mathrm{~cm}$.

\section{Pembahasan}

Hasil penelitian menunjukkan bahwa komposisi media berpengaruh nyata terhadap panjang tubuh buah dan jumlah tubuh buah, sedangkan untuk munculnya pin head, frekuensi panen, diameter tubuh buah, berat tubuh buah tiap panen, dan berat tubuh buah pengaruhnya belum terlihat secara nyata. Perlakuan ketebalan casing memberikan pengaruh nyata terhadap panjang tubuh buah saja, sedangkan pada peubah lainnya pengaruhnya belum terlihat secara nyata. Terdapat interaksi antara perlakuan komposisi media dan perlakuan ketebalan casing terhadap berat tubuh buah tiap panen.

Perlakuan komposisi media berpengaruh nyata terhadap panjang tubuh buah dan jumlah tubuh buah. Jumlah tubuh buah dipengaruhi oleh penyerapan nutrisi dalam media. Menurut Munawar (2011), nitrogen (N) berfungsi sebagai komponen utama protein, vitamin, dan enzimenzim esensial untuk kehidupan organisme. Perlakuan terbaik terdapat pada komposisi media TKKS + kapur + bekatul + tepung jagung. Sedangkan secara rataan, komposisi media terbaik terdapat pada media TKKS + kapur + bekatul + tepung jagung secara umum memiliki frekuensi panen, diameter tubuh buah dan berat tubuh buah. Penggunaan media TKKS + kapur + bekatul + tepung jagung memberikan pertumbuhan dan hasil yang lebih baik dibandingkan dengan media lainnya. Hal ini sesuai dengan hasil penelitian Hidayati et al., (2015), menunjukkan bahwa pada semua kelompok perlakuan yang menggunakan TKKS pada pertumbuhan jamur merang tampak lebih baik dibandingkan kontrol. Pertumbuhan miselia, primordia dan tubuh buah jamur yang dihasilkan oleh media dengan TKKS lebih cepat dan lebih baik secara kualitas serta kuantitasnya dibandingkan kontrol. Sutarja (2010), menyatakan komposisi campuran dalam budidaya jamur mempunyai pengaruh cukup baik sepanjang tingkat komposisi campuran berada pada kalkulasi yang tepat. Hal ini tampak pada komposisi campuran tepung jagung yang paling baik pada komposisi campuran 20\% sedang untuk bekatul pada komposisi 30\%, ada kecenderungan semakin tinggi tingkat komposisi campuran produksi jamur semakin meningkat. Maulidina et al., (2015), menyatakan pada media yang menggunakan campuran tepung jagung, selain mendapat asupan protein dan karbohidrat, jamur juga memperoleh glukosa yang berfungsi sebagai asupan energi dan metabolisme sel. Sedangkan untuk munculnya pin head jamur merang secara rataan memiliki nilai tertinggi pada perlakuan media TKKS + kapur + bekatul (kontrol).

Perlakuan ketebalan casing memberikan pengaruh nyata terhadap panjang tubuh buah. Perlakuan tanpa casing memberikan pengaruh nyata panjang tubuh buah jamur merang, sedangkan pada peubah lainnya pengaruhnya belum terlihat secara nyata. Akan tetapi secara rataan perlakuan tanpa casing juga memberikan nilai tertinggi terhadap munculnya pin head, frekuensi panen, diameter tubuh buah dan panjang tubuh buah. Sedangkan untuk munculnya pin head, jumlah tubuh buah dan berat tubuh buah jamur merang secara rataan memiliki nilai tertinggi pada perlakuan ketebalan casing $5 \mathrm{~cm}$. Setiyono et al., (2010), menyatakan semakin tebal media diperkirakan kandungan nutrisi lainnya juga semakin banyak, tetapi dari data yang diperoleh justru sebaliknya, T3 dengan ketebalan $35 \mathrm{~cm}$ memberikan hasil paling kecil jika dibandingkan dengan media dengan ketebalan $15 \mathrm{~cm}$ dan $25 \mathrm{~cm}$. Hal ini diakibatkan kandungan air yang terdapat pada media dengan ketebalan $35 \mathrm{~cm}$ memiliki kandungan air yang cukup tinggi sehingga diperkirakan kandungan air dan amoniak juga tinggi. Tinggi kandungan air dan amoniak dapat menghambat pertumbuhan jamur dan sangat memungkinkan tumbuhnya jamur liar.

Terdapat interaksi antara perlakuan komposisi media dan ketebalan casing terhadap berat tubuh buah tiap panen. Penggunaan komposisi media TKKS + kapur + bekatul + tepung jagung dan ketebalan casing $5 \mathrm{~cm}$ menunjukkan pengaruh nyata terhadap berat tubuh buah tiap panen. Dalam proses 
pertumbuhan jamur merang selain tergantung pada nutrisi yang tersedia dalam media juga dipengaruhi faktor lingkungan. Ketebalan, jenis media dan cara penempatan media tumbuh akan menciptakan kondisi lingkungan terutama suhu, kelembaban (Setiyono et al., 2010).

Media jamur merang yang disebut dengan kompos merupakan sumber makanan bagi benih jamur. Pertumbuhan dan perkembangan jamur sangat dipengaruhi oleh kualitas media dan komposisi yang digunakan. Benih jamur akan tumbuh dengan baik pada media yang memungkinkan oksigen mudah tersedia, $\mathrm{pH}$ tidak menunjukkan reaksi asam dan cukup mengandung zat-zat makanan. Kualitas media sangat ditentukan oleh bahan baku (sumber nutrisi) bahan tambahan dalam proses fermentasi dan proses pasteurisasi (Krisnawati, 1998; dalam Subaryanto, 2011).

Penyebab perbedaan variabel pengamatan tersebut dikarenakan terjadinya penurunan suhu media tanam pada perlakuan ketebalan media tumbuh tertentu. Hasil tersebut diperkuat oleh Adiyuwono (2002) yang mengemukakan bahwa semakin tinggi tumpukan media tanam maka suhu dalam media tanam tersebut juga akan semakin tinggi. Sinaga (2011) juga melanjutkan bahwa, pada suhu dibawah 30 ${ }^{\circ} \mathrm{C}$ akan menyebabkan pembentukan tubuh buah cepat tetapi kecil dan tangkainya panjang tetapi kurus serta payung akan mudah membuka sehingga hasil produksinya buruk.

\section{Kesimpulan}

Dari hasil penelitian ini dapat disimpulkan sebagai berikut:

1. Komposisi media TKKS + kapur + bekatul + tepung jagung berpengaruh nyata terhadap panjang tubuh buah, jumlah tubuh buah dan berat tubuh buah tiap panen.

2. Perlakuan tanpa casing memberikan pengaruh nyata terhadap panjang tubuh buah jamur merang.

3. Terdapat interaksi antara komposisi media dan ketebalan casing terhadap parameter pengamatan berat tubuh buah tiap panen.

\section{Daftar Pustaka}

Hidayati, Mohammad, R., dan Asmawit. 2015. Pemanfaatan Serat Tandan Kosong Kelapa Sawit Sebagai Media
Pertumbuhan Jamur Tiram Putih. Biopropal Industri 6(2): 73-80.

Ichsan, C.N., Harun, F., dan Ariska, N. 2011. Karakeristik Pertumbuhan dan Hasil Jamur Merang (Volvariella volvaceae) pada Media Tanam dan Konsentrasi Pupuk Biogreen yang Berbeda. (6) : 171180.

Maulana, E, 2012. Panen Jamur Tiap Musim (Panduan Lengkap Bisnis dan Budidaya Jamur Tiram, Lily Publisher. Yogyakarta.

Maulidina, R., Wisnu, E. M., dan Nawawi, M. 2015. Pengaruh Umur Benih dan Komposisi Media Tanam Terhadap Pertumbuhan dan Hasil Jamur Tiram Putih (Pleurotus ostreatus).Fakultas Pertanian. Universitas Brawijaya. Malang. Jurnal Produksi Tanaman. 3 (8): $649-657$.

Mayun, I.A. 2007. Pertumbuhan Jamur Merang (Volvariella volvacea) pada Berbagai Media Tumbuh. Universitas Udayana Denpasar. Fakultas Pertanian. Bali. Jurnal AGRITROP. 26(3):124-128.

Munawar A. 2011. Kesuburan Tanah dan Nutrisi Tanaman. Bogor: IPB press. hal 30.

Parjimo dan Andoko, A. 2008. Budidaya Jamur : Jamur Kuping, Jamur Tiram, dan Jamur Merang. Agromedia Pustaka. Jakarta.

Parjimo H., dan Soenanto H. 2008. Jamur Ling Zhi : Raja Herbal, Seribu Khasiat: Plus Cara Budi Daya. PT Agromedia Pustaka. Jakarta.

Pasaribu, T., D.R. Permana, dan E.R. Alda. 2002. Aneka Jamur Unggulan yang Menembus Pasar. Grasindo. Jakarta.

Pratiwi, R., Rahayu, D., dan Barliana, I.M. 2016, Pemanfaatan Selulosa dari Limbah Jerami Padi (Oryza sativa) sebagai Bahan Bioplastik. Fakultas Farmasi Universitas Padjadjaran. Sumedang. 3(3): 83-91.

Riduwan, M., Hariyono, D., dan Nawawi, M. 2013. Pertumbuhan dan Hasil Jamur Merang (Volvariella volvacea) pada Berbagai Sistem 
Penebaran Benih dan Ketebalan Media. Jurnal Produksi Tanaman. 1(1).

Sa'id, E. G. 1994. Penanganan dan Pemanfaatan Limbah Industri Kelapa Sawit. Badan Kerjasama Pusat Studi Lingkungan. Bogor.

Setiyono, Gatot, dan Ademarta, R. 2010. Pengaruh Ketebalan dan Komposisi Media Terhadap Pertumbuhan dan Hasil Jamur Merang. Fakultas Pertanian. Universitas Jember. Jurnal Ilmu-Ilmu Pertanian. 54-60.

Sinaga, M. S. 2011. Jamur Merang dan Budidayanya. Penebar Swadaya. Jakarta.

Siregar, M., dan Ritonga, E.S. 2014. Tanggap Pertumbuhan Jamur Merang Terhadap Formulasi dan Ketebalan Media. Jurnal Dinamika Pertanian. 29(3) : 225-230.

Suhardiman, P. 2006. Jamur Merang dan Mushroom,Pusat Penelitian Yayasan Sosial Tani Membangun. Jakarta.

Sudirman, L.I, Sutrisna, A., Listiyowati, S.,Fadli, L. and Tarigan. 2011. The Potency of Oil Palm Plantation Wastes for Mushroom Production. In Proceedings of the $7^{\text {th }}$ International Conference on Mushroom Biology and Mushroom Products (pp. 383-389). France.

Sumiati, E dan G. A. Shopa. 2009. Aplikasi Jenis Bahan Baku dan Bahan Aditif Terhadap Kualitas Media Benih Induk Jamur Shiitake. Jurnal Hortikultura. 19 (1): 4958.
Suriawiria, U. 2006. Sukses Beragrobisnis Jamur Kayu: Shiitake, Kuping, Tiram. Penebar Swadaya. Jakarta.

Sutarja. 2010. Produksi Jamur Tiram (Pleorotus ostreatus) pada Media Campuran Serbuk Gergaji Dengan Berbagai Komposisi Tepung Jagung dan Bekatul [Tesis]. Universitas Sebelas Maret. Surakarta.

Warmada, I.W., dan Titisari, A. D., 2004, Agromineralogi (Mineralogi untuk Ilmu Pertanian). Jurusan Teknik Geologi Fakultas Teknik UGM. Yogyakarta.

Widyastuti, B. 2008. Budidaya Jamur Kompos: Jamur Merang, Jamur Kancing (Champignon). Penebar Swadaya: Jakarta.

Widyastuti N., dan D. Tjokrokusumo. 2008. Aspek Lingkungan Sebagai Faktor Penentu Keberhasilan Budidaya Jamur Tiram (Pleurotus sp.). Jurnal Teknik Lingkungan. 9: 287-293.

Winarni, I dan U. Rahayu. 2002. Pengaruh Formulasi Media Tanam dengan Bahan Dasar Serbuk Gergaji Terhadap Produksi Jamur Tiram Putih (Pleurotus ostreatus). Jurnal Matematika, Sains dan Teknologi. Jakarta. 3(2) : 20-27.

Zuyasna, Nasution, M., dan Fitriani, D. 2011. Pertumbuhan dan Hasil Jamur Merang Akibat Perbedaan Media Tanam dan Konsentrasi Pupuk Super a-1. (6) : 92103. 